AIR WAR COLLEGE

AIR UNIVERSITY

\title{
THE “FIFTH” ARMY WAR COLLEGE: PREPARING STRATEGIC LEADERS TO WIN IN A COMPLEX WORLD
}

\author{
by \\ John M. Cyrulik, Colonel, United States Army \\ A Research Report Submitted to the Faculty \\ In Partial Fulfillment of the Graduation Requirements \\ Advisor: Dr. Douglas Peifer
}

17 February 2015 


\section{Report Documentation Page}

Form Approved

OMB No. 0704-0188

Public reporting burden for the collection of information is estimated to average 1 hour per response, including the time for reviewing instructions, searching existing data sources, gathering and maintaining the data needed, and completing and reviewing the collection of information. Send comments regarding this burden estimate or any other aspect of this collection of information,

including suggestions for reducing this burden, to Washington Headquarters Services, Directorate for Information Operations and Reports, 1215 Jefferson Davis Highway, Suite 1204, Arlington

VA 22202-4302. Respondents should be aware that notwithstanding any other provision of law, no person shall be subject to a penalty for failing to comply with a collection of information if it

does not display a currently valid OMB control number.

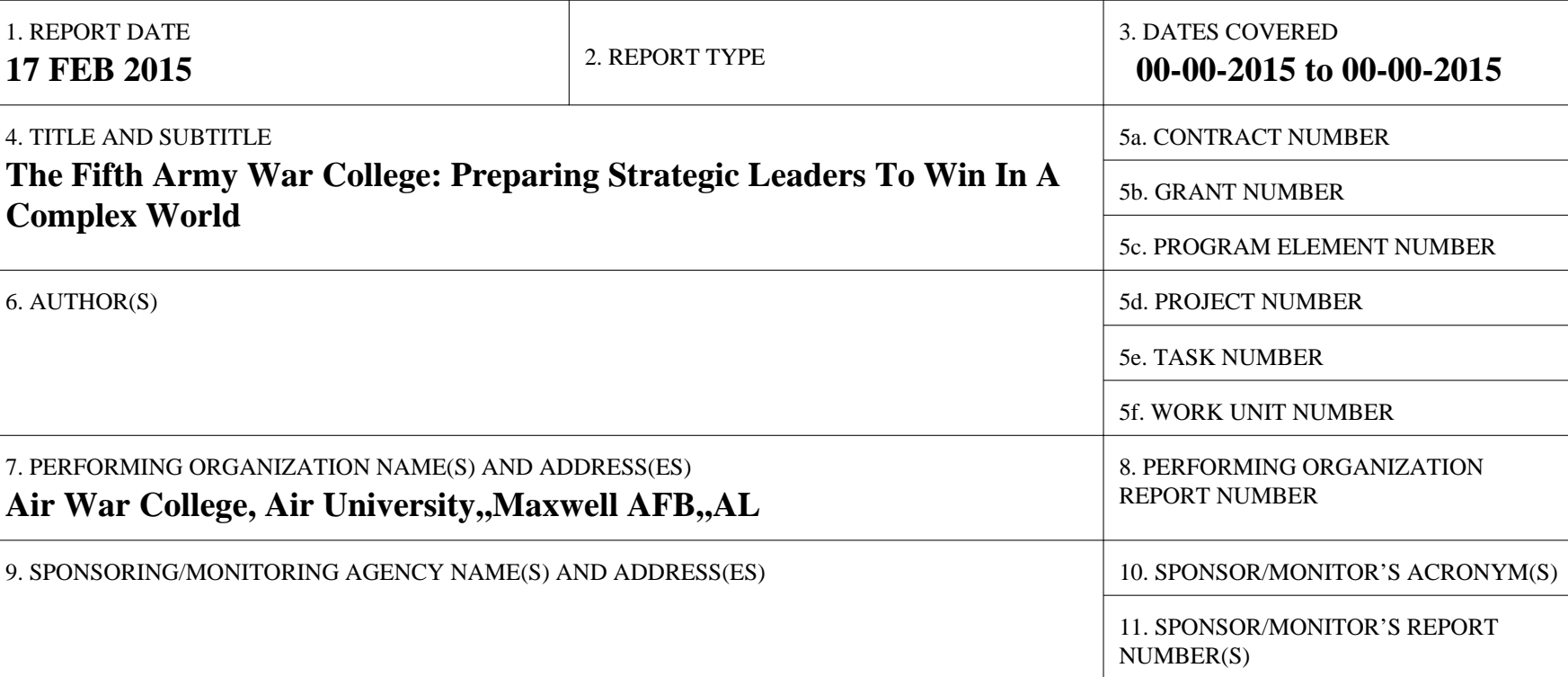

12. DISTRIBUTION/AVAILABILITY STATEMENT

Approved for public release; distribution unlimited

13. SUPPLEMENTARY NOTES

14. ABSTRACT

The United States Army War College (USAWC) has played an important role in the education and development of strategic leaders for over a century. Throughout its history, the USAWC has adapted and evolved to better prepare senior leaders for a variety of strategic environments and challenges. The history of the USAWC can be divided into four distinct eras each of which has contributed to the present war college curriculum.

15. SUBJECT TERMS

16. SECURITY CLASSIFICATION OF:

\begin{tabular}{c|c|c|c|c|c}
$\begin{array}{c}\text { a. REPORT } \\
\text { unclassified }\end{array}$ & $\begin{array}{c}\text { b. ABSTRACT } \\
\text { unclassified }\end{array}$ & $\begin{array}{c}\text { ABSTRACT } \\
\text { c. THIS PAGE } \\
\text { unclassified }\end{array}$ & $\begin{array}{c}\text { OF PAGES } \\
\text { Report (SAR) }\end{array}$ & $\mathbf{2 7}$ & RESPONSIBLE PERSON \\
& & &
\end{tabular}




\section{DISCLAIMER}

The views expressed in this academic research paper are those of the author and do not reflect the official policy or position of the US government, the Department of Defense, or Air University. In accordance with Air Force Instruction 51-303, it is not copyrighted, but is the property of the United States government. 


\section{Biography}

COL John M. Cyrulik, United States Army, is assigned to the Air War College, Air University, Maxwell AFB, AL. He is an Army aviation officer who began his career in 1991 as an Army ROTC Distinguished Military Graduate of the State University of New York at Brockport. He has been stationed overseas in Panama, Alaska and Germany. His CONUS assignments include three tours at Fort Bragg, NC in the XVIII Airborne Corps and $82^{\text {nd }}$ Airborne Division and a tour in the Pentagon. COL Cyrulik has deployed five times to include the Bosnia-Herzegovina Stabilization Force (1997), Operation Allied Force in Albania (1999), Operation Iraqi Freedom (2005, 2006-07), and Operation Enduring Freedom (2011-2012).

While serving in Afghanistan, COL Cyrulik commanded Task Force Wolfpack, a multifunctional aviation battalion task force stationed at Forward Operating Base Salerno in Regional Command - East. He is a graduate of the U.S. Army Command and General Staff College and School of Advanced Military Studies at Fort Leavenworth, KS. He is a master army aviator with over 2,000 flight hours, mostly flown in the AH-64 Apache attack helicopter. 


\begin{abstract}
The United States Army War College (USAWC) has played an important role in the education and development of strategic leaders for over a century. Throughout its history, the USAWC has adapted and evolved to better prepare senior leaders for a variety of strategic environments and challenges. The history of the USAWC can be divided into four distinct eras, each of which has contributed to the present war college curriculum. This Professional Studies Paper advocates for the beginning of a "Fifth" USAWC Era to best prepare senior leaders to "Win In a Complex World." The "Fifth" USAWC Era should include some of the best parts of the previous periods that have been recently overlooked, but served the Army and the Nation well in past times of war and peace. This new era should include the four primary recommendations of this study; a "War Plan of the Year" course akin to the early $20^{\text {th }}$ century "Main Problem" studies, overseas travel as part of an expanded Regional Studies Program, a dedicated yearlong military history course, and reviving the eight-week Military Research Program of the 1970 s.
\end{abstract}




\section{Introduction}

In the Winter 1995-96 issue of Parameters, the US Army War College Quarterly, Major General (MG) Richard A. Chilcoat, the $43^{\text {rd }}$ Commandant of the Army War College, published an article describing a new period of development in the college's illustrious history. He named this era the "Fourth" Army War College (USAWC) that would best prepare strategic leaders for the early $21^{\text {st }}$ century by largely using the power of the microprocessor and other Information Age technologies. ${ }^{1}$ An updated USAWC Strategic Action Plan guided the change with a fresh vision, mission, and objectives. MG Chilcoat envisioned the "Fourth" USAWC lasting fifteen to twenty years, when a new cycle of change would be required to ensure the college remained "the nation's preeminent center for strategic leadership and landpower." ${ }^{2}$ This leads us to the present, and the requirement for a "Fifth" USAWC to prepare senior leaders to "Win In a Complex World." An effort is underway at the USAWC to significantly change the curriculum and the "Carlisle Experience." Army War College Era that would include the four primary recommendations of this study which are a "War Plan of the Year" course akin to the early $20^{\text {th }}$ century "Main Problem" studies, overseas travel as part of an expanded Regional Studies Program, a dedicated yearlong military history course, and reviving the eight-week Military Research Program of the 1970s. This paper begins with a brief description of the future strategic operating environment envisioned by the Army and the leadership qualities required to meet the challenges of operating in this new paradigm, from which the next war college era should emerge. This study then continues with an overview of the four previous USAWC periods before offering a set of recommendations for inclusion in the current USAWC change process. 


\section{The Army's Vision of the Future and Strategic Leadership Competencies}

The Army completed two vitally important publications in 2014. The first was the muchanticipated U.S. Army Operating Concept: Win in a Complex World 2020-2040. This work "provides the intellectual foundation and framework for learning and for applying what we learn to future force development under Force 2025 and Beyond." ${ }^{5}$ The TRADOC Commanding General's foreword emphasizes that the Army Operating Concept's "vision of the future must drive change to ensure that Army forces and prepared to prevent conflict, shape the security environment, and win wars." ${ }^{6}$ The Army Operating Concept includes an acknowledgment of the "continuities in the nature of war as well as an appreciation for changes in the character of armed conflict" and references Thucydides and Clausewitz. ${ }^{7}$ The themes that emerge from the Army Operating Concept's vision of the future include: complexity, ambiguity, multiplicity, adaptation, and innovation. Two days after the release of the Army Operating Concept, the Army's Human Dimension White Paper was signed at Fort Leavenworth, KS. The white paper "presents a vision for how the Army will optimize human performance" in support of the new operating concept. ${ }^{8}$ Most importantly for the purposes of this study, the white paper describes the qualities required for leaders to achieve a "Strategic Win." It states:

The Army of the future must produce leaders, at every level, who think broadly about the nature of the conflict in which they are engaged. They must have a nuanced appreciation of social context, and an ability to develop strategically appropriate, ethical solutions to complex and often-violent human problems. Future leaders must innovate rapidly on the battlefield. They must have a highly refined sense of cultural empathy and a social intuition for their operational environment. Finally, future leaders must be able to appreciate the wider strategic context in which their actions take place, always prepared for global scrutiny as the smallest tactical actions can be broadcast live to a global audience. To meet these demands, Army leaders from fire team to theater command must be agile and adaptive, physically strong and resilient, and appropriately educated warriors of the Army Profession, with superb critical thinking skills and broad cultural understanding. ${ }^{10}$ 
Taken together, these two important Army publications do an excellent job in describing what competencies future war college graduates should possess. In sum, to win in a complex and uncertain world, senior leaders must be superb critical thinkers; appreciate the historical, social, and cultural context; think and operate strategically and ethically; be adaptive and innovative, and have broad cultural understanding.

This is not the only period in the one hundred and twelve years since the foundation of the USAWC that the Army has been faced with a complex and uncertain world. The previous four war college eras contained plenty of unknowns and a myriad of strategic dilemmas requiring critically thinking senior leaders who understood the context of their times, coupled with a fundamental understanding of the nature of conflict and war, informed by history, and often operating as part of a coalition or alliance in distant lands thus requiring broad cultural savvy. And the Army has also faced a variety of determined, adaptive, and potent enemies and threats throughout the $20^{\text {th }}$ and early $21^{\text {st }}$ centuries. The next sections include a review of past war college eras while considering what is the best course on which the future USAWC should embark.

\section{The Four Previous Army War College Eras}

\section{The Framework}

The framework that divides up the history of the USAWC into distinct eras can be credited to Colonels George S. Pappas and Harry P. Ball, who have authored the two most extensive histories of the Army War College. ${ }^{11}$ Pappas' work, Prudens Futuri: The US Army War College 1901-1967, first established "three distinct periods" of USAWC history, but only chronicled the College's past until the graduation of the Class of 1966, which was the fiftieth cohort. $^{12}$ Ball's book, Of Responsible Command: A History of the U.S. Army War College, was 
published in 1984 and revised ten years later. It is the most comprehensive single volume history of the Army War College. In the preface to the original and revised editions Ball partitioned the history of the college into three parts. The first period included the formation of the USAWC in 1903 and the formative first years until classes were suspended with the United Sates entry into World War I in 1917. The second part of the Army War College history began at the end of World War I with the Class of 1919 and lasted until 1940 when classes were suspended again, this time for a full decade while the Army fought and won World War II. The third war college period started with the resumption of studies in 1950 at the beginning of the Nuclear Age and Cold War and concludes with the passage of the Goldwater-Nichols Department of Defense Reorganization Act in 1986 and the collapse of the Soviet Union in 1991. ${ }^{13}$ The fourth war college era commences with the reforms directed by the GoldwaterNichols Act and MG Chilcoat's vision as Commandant and continues until today. As recently as three years ago, the 2011-12 USAWC Catalogue declared that the college "is currently in the midst of its fourth incarnation.",14

\section{The First Army War College Era (1903-1917)}

War Department General Order 155, dated 27 November 1901, established the Army War College as an "advanced course of professional study" to be located at Washington Barracks in the District of Columbia. ${ }^{15}$ Secretary of War Elihu Root, who began a "significant process of innovation and reform" of the War Department and the Army at the turn of the century, signed the order. ${ }^{16}$ The Root Reform Era between the Spanish-American War and World War I "saw vast changes in the entire fabric of the US Army." ${ }^{17}$ The creation of the Army War College is one of the most lasting and important Root reforms. 
The "First" USAWC era was a period of rapid institutional evolution and had several distinctive characteristics, some of which may still have value today. First and foremost, the Classes of 1905 and 1906 served as an extension of the Army General Staff and spent a majority of their time developing and improving the various standing war plans. They explored new technologies and planned for a variety of contingencies, to include potential employment of Army forces to several likely overseas hot spots. There was no formal curriculum, and the students largely immersed themselves in solving practical military problems for the Sectary of War and newly created office of the Chief of Staff of the Army. ${ }^{18}$

Only six years into its existence, the USAWC went through the first of many significant changes. In 1907, the college began evolving from an annex of the General Staff to a quasieducational institution that focused on military history and the art of command and staff with a series of formal coursework, lectures, and Civil War battlefield staff rides championed by Major Eben Swift, while also requiring students to continue real-world contingency planning. ${ }^{19} \mathrm{~A}$ tension between the demands of practical problem solving for senior Army leaders and a broader education rooted in military history and tactics emerged by 1910, and still exists within United States Professional Military Education to some degree today.

A third variation of the First USAWC era materialized by 1910 and lasted until 1917. While the first variant was largely an extension of war planning for the General Staff, and the second focused on military history and contingency planning, the third version was dominated by a series of tactical problems and field exercises to improve the conduct of military operations, with a foundational course of military history. Of note, two Navy officers joined the Class of 1906-07, the first students from a sister service, in an effort to increase Army-Navy cooperation. ${ }^{20}$ Perhaps most importantly, the yearlong program included a "War Plan of the 
Year" strategic review, based off the Navy War College "Main Problem" exercises, where the students would game the actual war plans "in an effort to test the feasibility, completeness, and effectiveness of the plans concerned." ${ }^{21}$ Although the main focus of the First War College Era fluctuated during these early formative years, the emphasis on real-world planning in an effort to improve the nation's war plans, foster inter-service knowledge and cooperation, and understand the strategic environment stands out among other facets.

\section{The Second Army War College Era (1919-1940)}

The War College resumed classes in 1919 after a two-year suspension during the American involvement in World War I. During the war many War College graduates served in key senior positions either in the War Department or overseas with the American Expeditionary Forces in Europe. ${ }^{22}$ The Army's experience during the war and the lessons learned shaped the inter-war year curriculum significantly. Although several characteristics of the pre-war era were maintained, three fundamental changes occur during the 1920s and 30s. These were the expansion of the curriculum to include a study of other instruments of national power to include politics and foreign diplomacy, economic and industrial policy related to the conduct of war; the expansion of committee work by students to solve the vexing problems faced by the Army and the War Department; and the dramatic increase in number of outside experts and guest speakers as part of the "informative period" or "Preparation for War" phase of the course. ${ }^{23}$ In addition, the development of strategic estimates, study of Clausewitz's treatise On War, and emphasis on military history and biography coupled with an examination and improvement of the "Rainbow" war plans largely characterized the Second Army War College Era. Lastly, significant tension emerged within the War College between the requirements to train and educate future General Staff officers of the various branches versus preparing senior officers for high command 
positions. $^{24}$ In fact, from its reopening in 1919 until 1922 the college was officially named the General Staff School reflecting the priority to train staff officers identified to serve at the Field Army, Theater, and War Department levels. ${ }^{25}$

While many of the characteristics of the Second Army War College era endure to this day, such as a focus on national security affairs and the strategic level of warfare; a robust guest lecturer and speaker program with a policy of non-attribution to spur debate and controversy; and an emphasis on joint service cooperation; two key facets of this era deserve additional examination. The first characteristic is the primacy of the student committee as the means through which the training and education took place. Students were organized into committees for most assignments with the express purpose "to learn and gain understanding from each other and from the experience of participating in collective problem-solving exercises." ${ }^{26}$ Committee leadership rotated throughout the year, and each assignment culminated in a written and often oral presentation to a conference of faculty and others who would then review and critique the committee's solution. ${ }^{27}$ The other important characteristic of this era was the division of the program into two distinct phases, the "Preparation for War" phase, which began in September and lasted until February to be followed by the "Conduct of War" phase which lasted until the academic year ended in June. The Conduct of War phase dedicated a full sixteen weeks to war gaming, strategic reconnaissance, along with field maneuvers and command post exercises. To be sure, although the Second War College broadened the scope of officer education to include a variety of strategic subjects, the course remained commendably focused on the Army's core mission to fight and win the nation's wars in a volatile, uncertain, and complex world. 


\section{The Third Army War College Era (1950-1989)}

The longest of the four USAWC eras began after World War II and lasted until the end of the Cold War. Following a ten year suspension of classes from 1940-1950, the War College reopened for one year at Fort Leavenworth, KS before relocating for a final time to Carlisle Barracks, PA in 1951. The original location of the Army War College in Washington, DC became the home of the newly established National War College. The nearly five year delay between the end of the Second World War and reopening of the USAWC was due to a fairly contentious debate on the future of all the military war colleges and the creation of the Department of Defense in $1947 .^{28}$ Similar to the prior two eras, the Third War College era included frequent changes in the curriculum as the Army adapted to the realities of the Cold War, Superpower status, and the Nuclear Age.

The Third Army War College Era began largely where the Second Era ended a decade earlier. The ten month long program was divided into three phases; The Army and National Security, Current Army Problems, and War Planning. The "Committee System of Problem Solution" 29 remained the primary instructional method, and priority was placed on completing staff studies and recommendations on a variety of complex problems faced by the Army at the time. For example, the Class of 1950-51 studied the Forced Retirement of Colonels at 30 Years Commissioned Service and Assignment of Women to Zone of Interior Combat Units in Wartime. ${ }^{30}$ In addition to committee work, students were required to write a 4,000-6,000-word research paper on one of ten general subject areas. Once complete, the officer conducted an oral presentation of his paper to the entire class prior to graduation. ${ }^{31}$ In present-day parlance, much of the work completed by the students in the early 1950's can be considered "think tank" type studies now completed by the Army's highly regarded Strategic Studies Institute at Carlisle 
Barracks or the RAND Corporation's Army Research Division. ${ }^{32}$ By 1957, under the watchful eye of Chief of Staff of the Army GEN Maxwell D. Taylor, the USAWC instituted a new curriculum in which "war games and planning waned; strategy and doctrine to support strategy waxed." ${ }^{33}$

By 1960 the Cold War era curriculum had generally stabilized, the committee system of problem solving still dominated, and three lasting characteristics of the Carlisle Experience became integral parts of the USAWC program. The first trip to the United Nations occurred in 1950, the annual Gettysburg Staff Ride began in 1951, and the first National Security Seminar convened in 1955. The Academic Year 1961-62 is a good example of the curriculum and structure of the early Third Army War College Era. It represents a significant shift from solving current Army problems and war planning. The forty and a half week course was divided into three parts; National Power and International Relations, Military Power and National Security Policy, and National Strategy and Military Program. Only one of the seven core courses focused on the Army or land warfare. ${ }^{34}$ The study of military history and biography had largely vanished from the curriculum. The National Security Seminar replaced the end of year war game as the culminating event. Of note, 1961 also marks the first-time that a civilian university collaborated with the Army War College to provide a Masters Degree program to students who volunteered for additional coursework. ${ }^{35}$ George Washington University offered a Master of Arts in International Affairs degree to the class members, and 88 of 202 students took advantage of the program in 1961-62. ${ }^{36}$ Even though the cooperative degree program between the Army War College and George Washington University proved popular, it was short lived and discontinued in 1966 due to a variety of factors. ${ }^{37}$ The USAWC had not yet fully become the modern academic institution that would be most recognized by recent faculty and alumni today, but the 
transition in the early 1960's marks a tipping point towards College vice Army and War in United States Army College identity.

The experience of the Army during the Vietnam War had a significant impact of the Army War College in the 1970s and 80s. Beginning in 1971, the USAWC chartered a new course to become "the center of contemporary military thought" and an "intellectual center" where students studied subjects such as ideology, sociology, the military and society, and political order. ${ }^{38}$ This vision continued to move the USAWC away from an immersive study of warfare and military leadership. The students increasingly interacted with corporate and other civilian leaders, visiting municipal governments, labor unions, media organizations, and other offices whiles visiting New York City each year. ${ }^{39}$ Additionally, the College began to offer a variety of electives to the students beginning in 1967.

Two other important lasting changes occurred in the latter half of the Third Army War College Era. In an effort to provide U.S. students foreign points of view and further enrich the Carlisle Experience, the USAWC created the International Fellows Program in 1977. In 1979 twenty different foreign armies sent thirty-two officers to the Army War College. Rather than grant access to significant amounts of classified information to the International Fellows, the inclusion of foreign officers in the class largely led to the removal of classified information from the curriculum, which had already been tackled by the College when it established the Corresponding Studies (non-resident) program a few years earlier. ${ }^{40}$ Most importantly, the War College adopted the student seminar over the committee as the backbone of the educational experience. Each seminar consisted of approximately sixteen students from the various Army branches, other military services and government agencies, and included an International Fellow or two. "With this rich heterogeneous mix of students, incorporating introspective discussions 
facilitated by capable and experienced faculty members, and employing a variety of readings, guest lectures, and written assignments, the seminar method would provide a rich learning environment." ${ }^{41}$

\section{The Fourth Army War College Era (1989-Present)}

The passage of the Goldwater-Nichols Department of Defense Reorganization Act of 1986 and the end of the Cold War mark the beginning of the Fourth Army War College Era. The effects of the Goldwater-Nichols Act on the Army War College were dramatic. ${ }^{42}$ The Act established standards for Joint Professional Military Education (JPME) and the Program for Assessment of Joint Education (PAJE). The Chairman of the Joint Chief of Staff (CJCS) Officer's PME Policy (OPMEP) issued by the Joint Staff includes "the policies, procedures, objectives and responsibilities for PME and JPME." ${ }^{\text {43 }}$ The OPMEP is hugely influential on the Army War College, and dictates, among other things, class and seminar composition, faculty mix and qualifications, student to faculty ratios, and comprehensive Joint Learning Areas and Objectives. The OPMEP was largely influenced by the nine major recommendations of the 1989 Report of the Panel on Military Education of the $100^{\text {th }}$ Congress of the Committee on Armed Services chaired by Representative Ike Skelton. ${ }^{44}$

The USAWC completed the initial transition directed by the OPMEP by 1992 and then began a period of incremental, but substantial change between 1993 and 2005. This period was initially spurred on by MG Chilcoat's vision of an Information Age war college and continued after the terrorist attacks of September 11,2001. The changes at the USAWC were so significant over these years that one report stated, "Without exaggeration, a faculty member from 1993 would hardly recognize the current curriculum. ${ }^{, 45}$ The 2003 academic program is a good example of the period. The Seminar Learning Model remained the "the basic organizational and 
instructional unit at the USAWC." The 2003 curriculum consisted of four core courses: (1) Strategic Leadership, (2) War, National Security Policy, and Strategy, (3) Joint Processes and Landpower Development, and (4) Implementing National Military Strategy. Also included were Regional Strategic Appraisals, a Strategic Crisis Exercise, and a total of seven electives. The Gettysburg Staff Ride, New York City and Washington D.C. trips, and National Security Seminar rounded out the ten-month program. Each student also completed a Strategy Research Project and had the opportunity to participate in a variety of Special and Complimentary Programs designed to "broaden individual development and to allow students to choose subjects that best suited their personal needs." 46

While the USAWC academic program transformed into a highly personalized educational and development experience emphasizing JPME during the first decade of the $21^{\text {st }}$ century, another transformation was taking place with regards to the faculty. By 2005 the class size had grown to 334 students, including 54 officers from the other military services, 24 civilians representing various governmental departments and agencies, and 41 International Fellows. ${ }^{47}$ Educating these students was the responsibility of 134 faculty members, of which 72 (54\%) were military officers and 62 (46\%) civilians. In contrast, during the first three war college eras the faculty was overwhelmingly military. During 1954, a request to hire the first two civilian professors was stonewalled by the Department of the Army. In 1972-73, only four civilianscholars were in residence at the College. ${ }^{48}$ By 1993 that number had grown to 36 (35\%) civilian faculty members. Additionally, the Army War College strove for, and was eventually granted, accreditation from Middle States Association of Colleges and Schools to award a Master of Strategic Studies degree using the resident and non-resident curriculum. ${ }^{49}$ The offering of a array of electives, which comprised as much as $85-90 \%$ of student hours ${ }^{50}$, coupled with the 
rapid increase of civilian faculty members and the requirements for degree accreditation completed the trend where the USAWC exists as a College, rather than a place where military officers studied the Army and War as a primary focus.

More than a decade of war in Afghanistan and Iraq has led to additional changes in the Carlisle Experience and the most recent USAWC curriculum. There are now five core courses with a renewed emphasis on Theater Strategy and Campaigning, which had been an important part of the curriculum for most of the College's history. Of note, the number of International Fellow is now 79; almost double the number of just a decade ago. The USAWC now also grants both JPME I and II credit to graduates. ${ }^{51}$ The current USAWC program is a sum of many of its past adaptations and evolution. Each of the four Army War College Eras has contributed to its present form.

\section{Recommendations}

A "Fifth" Army War College Era should include some of the best parts of the previous periods that have been recently overlooked, but served the Army and the Nation well in past times of war and peace. This paper does not necessarily propose eliminating any of the current Army War College parts. Inclusion of the first two recommendations below is additive and is possible by extending the length of the course by eight weeks. The same holds true for the fourth recommendation. Depending on the career field and expertise of the officer, one could either participate in overseas travel and war planning for a combination of eight weeks, or contribute as part of the Military Research Program. An additional benefit of these programs added to the end of the academic year is that participation can be synched with the future assignment of the graduating Army officers. For example, a colonel slated to serve on the European Command staff would be able to study and then travel to the region and upon return 
examine, war game, and critique the command's key plans. A different officer, slated to serve on the Army Staff in the Pentagon, could work closely with other students to help study and solve the urgent problems faced by the Department of the Army with a group of peers. The chief recommendations of this paper are:

- A month at the end of the program for a "War Plan of the Year" course where students applied their new knowledge similar to the pre-World World I and Inter-War year curriculums. The concept itself was originally borrowed from and then improved upon the Navy War College's annual "Main Problem" studies. This would be a highly classified course primarily for U.S students, embracing "the study of actual problems involved in the preparation for and the conduct of war under existing conditions,,$" 52$ perhaps with allies or coalition members participating depending on the particular plan. This course would naturally follow and serve as an extension of the current Theater Strategy and Campaigning instruction.

- Overseas travel as part of an expanded Regional Studies Program. This has been explored in the past, but never adopted by the Army. ${ }^{53}$ It is inexplicable that an Army Operating Concept that emphasizes regional engagement and global response as core tenets would not send its newest senior leaders to the regions of most concern to observe the challenges firsthand. ${ }^{54}$ In addition, The Human Dimension White Paper stresses cultural education, regional expertise, and languages. ${ }^{55}$ In this regard, the Air War College at Maxwell AFB has the best model available for adoption by the Army. Each year the students travel across the globe in small groups to increase cultural awareness and gain first-hand knowledge of the strategic environment. Foreign 
language instruction is also offered at the Air War College to further enhance the Regional and Cultural Studies Program.

- A dedicated yearlong Military History Course with an emphasis on biography and the analysis of wartime strategic leadership followed by a study of the great military campaigns. Studies of George Washington, Ulysses S. Grant, George C. Marshall, Dwight Eisenhower, and other consummate Army generals should form the backbone of the biographical studies. This new core course would also promote the renewed emphasis on professionalism in the Army by studying the exemplars of past generations.

- Revive the eight-week Military Research Program of the mid-1970s to assist in solving the vexing problems faced by the Army. This will return the student committee problem-solving construct to the USAWC, although not for the entire academic year, but for the final two months of the course for those officers selected. Committees will operate analogous to the first fifty years of the War College's history and submit written staff reports and present their findings and recommendations to a conference of faculty and stakeholders of the particular problems examined. The committees will take direct guidance for the problems to be examined by the Chief of Staff of the Army through the Key Strategic Issues List, with a particular focus on the Special Interest Topics.

\section{Conclusion}

It is high time to begin a Fifth United States Army War College Era. The current era is now nearly three decades old. The strategic environment has changed dramatically since the end of the Cold War and the implementation of the Goldwater-Nichols Act in the late 1980s. The 
College, which has often exhibited the necessary agility to change during previous eras, should continue to return the focus of the program to the Army and War. The Army's struggles in both Iraq and Afghanistan should be all the motivation necessary to embark on serious and comprehensive change. Over the last fifty years, the pendulum has swung too far in the direction of international relations, political science, joint service matters, and individual academic pursuits. The return of robust war planning and war-gaming by all U.S. students, culminating in a highly classified "War Plan of the Year" exercise would be a good start. In addition, an indepth study of military history and biography, in a matter befitting the spirit of Representative Ike Skelton, to serve as the bedrock for senior leader education is highly recommended. ${ }^{56}$ The study and use of military history may be one of the best hedges in preparing strategic leaders to operate in an uncertain world. And the Army faces a myriad of problems that the exceptionally talented and experienced student body can assist in solving. The War College should leverage the students formed into various committees under the tutelage of the Strategic Studies Institute to serve as a quasi-extension of the Army Staff and bring fresh ideas from outside the Pentagon and the Beltway to solve the complex problems facing the Army today. Finally, the USAWC should adopt the Air War College's Regional and Cultural Studies overseas travel program to enhance cultural awareness and better understand the strategic environment. Both the addition of a regional studies trip and a culminating war game could be completed after the National Security Seminar week if necessary to avoid wholesale disruption of the current curriculum in the interim. None of the recommendations offered in this paper conflict with the OPMEP or other guidance from the Joint Staff, and can be implemented with the addition of relatively modest resources and expansion of the Army War College program to a full year. 


\section{Notes}

${ }^{1}$ MG Richard A. Chilcoat, "The "Fourth Army War College: Preparing Strategic Leaders for the Next Century," Parameters (Winter 1995-96): 3-17.

2 Ibid., 3,7.

${ }^{3}$ U.S. Army TRADOC Pamphlet 525-3-1, The U.S. Army Operating Concept: Win in a Complex World, 07 October 2014.

${ }^{4}$ United States Army War College, The Torch, Spring 2014. See page 3 "Academic 2013-2014: Year of initiatives, innovations, and 'firsts',"

http://www.carlisle.army.mil/banner/torch.pdf

${ }^{5}$ Army Operating Concept, i.

${ }^{6}$ Ibid., iii.

${ }^{7}$ Ibid., 6-7.

${ }^{8}$ United States Army Combined Army Center, The Human Dimension White Paper: A Framework for Optimizing Human Performance, 09 October 2014, 6.

${ }^{9}$ Army Operating Concept, iii.

${ }^{10}$ Human Dimension White Paper, 7.

${ }^{11}$ Also see Samuel J. Newland, "A Centennial History of the US Army War College," Parameters (Autumn 2001): 34-42 for another article that divides the War College history into four distinct eras.

${ }^{12}$ George S. Pappas, Prudens Futuri: The US Army War College, 1901-1967 (Carlisle Barracks, PA: Alumni Association of the United States Army War College, 1967,) 1.

${ }^{13}$ Harry P. Ball, Of Responsible Command: A History of the U.S. Army War College, Revised Edition (Carlisle Barracks, PA: Alumni Association of the United States Army War College, 1994), vii-x.

${ }^{14}$ United States Army War College, Curriculum Pamphlet, Academic Year 2012, page 3, http://dde.carlisle.army.mil/DDE_documents/Catalogue.pdf

15 War Department General Orders, No. 155. Dated 27 November 1901, http://www.history.army.mil/documents/1901/WDGO155-1901.htm

${ }^{16}$ James L. Yarrison, The U.S. Army in the Root Reform Era, 1899-1917, United States Army Center of Military History, 03 May 2001

http://www.history.army.mil/documents/1901/Root-Ovr.htm

${ }^{17}$ Ibid., Summary.

${ }^{18}$ William R. Donovan and Lynn Burlbaw, Aiming for Educated Officers: Curriculum Evolution in Early Professional Military Education in the United States, 1880-1914 (College Station, TX: Texas A\&M University, 2007), 27-28.

${ }^{19}$ Ball, Of Responsible Command, 100, 105-106.

${ }^{20}$ Pappas, Prudens Futuri, 50-51.

${ }^{21}$ See both Ball, Of Responsible Command, 106 and Pappas, Prudens Futuri, 57.

${ }^{22}$ Pappas, Prudens Futuri, 87.

${ }^{23}$ Ball, Of Responsible Command, 199 and Pappas, Prudens Futuri, 94, 97-98, 106.

${ }^{24}$ Ball, Of Responsible Command, 178-79.

${ }^{25}$ Pappas, Prudens Futuri, 97.

${ }^{26}$ Ball, Of Responsible Command, 248.

${ }^{27}$ Pappas, Prudens Futuri, 121 and Ball, Of Responsible Command, 213. 
${ }^{28}$ See Ball, Of Responsible Command, Chapter XIII entitled "Decision to Begin Anew: 1941-1950," 257-280 and Pappas, Prudens Futuri, Chapter VIII entitled "The Joint Era: 194550," 139-150 for historical coverage of the immediate post-war debate over the future of the Army War College.

${ }^{29}$ Combined Arms Research Library Digital Library, Fort Leavenworth History Collection, Army War College, Fort Leavenworth, Kansas, 1950-1951,

http://cgsc.contentdm.oclc.org/cdm/ref/collection/p4013coll4/id/337 created 09 September 2010.

${ }^{30}$ Ibid., 159-167.

${ }^{31}$ Ibid., 156.

${ }^{32}$ For a list of recent research completed by the US Army War College's Strategic

Studies Institute and RAND Corporation's Army Research Division visit the respective websites http://www.strategicstudiesinstitute.army.mil and http://www.rand.org/ard.html

${ }^{33}$ Judith Hicks Stiehm, The U.S. Army War College: Military Education in a Democracy, (Philadelphia, PA: Temple University Press, 2002), 37-38.

${ }^{34}$ Air University, A Study on Comparison of United States Senior Military Colleges for Academic Year 1961-1962, "Curriculum Outline of Service Military Colleges," Maxwell AFB, 1962. See Tab A, page 1 for the Army Curriculum.

${ }^{35}$ Ball, Of Responsible Command, 346-49.

${ }^{36}$ Ibid., See pages $8-9$ on the main study and Tab C-1 page 5 for information relating to the George Washington University Center and degree program.

${ }^{37}$ Ball, Of Responsible Command, 381-382.

${ }^{38}$ Stiehm, The U.S. Army War College, 40-42.

${ }^{39}$ Ball, Of Responsible Command, 447.

${ }^{40}$ Ball, Of Responsible Command, 449-50.

${ }^{41}$ Newland, "A Centennial History of the US Army War College," 39.

42 Jeffrey D. McCausland, Educating Leaders in an Age of Uncertainty: The Future of Military War Colleges, A Research Study for the Smith Richardson Foundation, 15 December 2005. See Chapter 2 "The Army War College: Educating Strategic Leaders in an Age of Uncertainty," page 48.

${ }^{43}$ Chairman of the Joint Chiefs of Staff Instruction, Officer Professional Military Education Policy, CJSC 1800.01D, current as of 05 September 2012. This is the fourth major revision of the OPMEP. See Page 1 for Purpose.

${ }^{44}$ U.S. House of Representatives, Committee on Armed Services Subcommittee of Oversight \& Investigations, Another Crossroads? Professional Military Education Two Decades After the Goldwater-Nichols Act and the Skelton Panel, April 2010, see pages 10-12.

${ }^{45}$ McCausland, Educating Leaders in an Age of Uncertainty, 49-53.

${ }^{46}$ United States Army War College, Curriculum Pamphlet, Academic Year 2003, 11-23.

${ }^{47}$ McCausland, Educating Leaders in an Age of Uncertainty, 145.

${ }^{48}$ Pappas, Prudens Futuri, 312-13, 420.

${ }^{49}$ McCausland, Educating Leaders in an Age of Uncertainty, 52.

${ }^{50}$ Stiehm, The U.S. Army War College, 175.

51 The United States Army War College website, "Military Level 1Programs" online at http://www.carlisle.army.mil/programs/mel_1.htm (accessed 13 December 2014).

${ }_{53}^{5}$ Pappas, Prudens Futuri, 116.

${ }^{53}$ Ball, Of Responsible Command, 434. 
${ }_{55}^{54}$ Army Operating Concept, 15.

${ }^{55}$ Human Dimension White Paper, 17.

${ }^{56}$ Representative Ike Skelton "long believed that the study of history, particularly military history, is the key to developing leaders and strategists." From the U.S. House, Another Crossroads? Page 11. Skelton remarked to cadets at West Point that "Every military officer should be a historian... if you are a student of history it will benefit you. Decisions you will have to make will be similar to decisions made in the Second World War. Think about it. You will be writing history. I guarantee it. Make it good." See USMA website, http://www.usma.edu/sosh/siteassets/sitepages/UJSS\%20Interviews/Skelton_Interview.pdf, (accessed 14 December 2014). 
Air University, A Study on Comparison of United States Senior Military Colleges for Academic Year 1961-1962, Maxwell AFB, 1962.

Ball, Harry P. Of Responsible Command: A History of the U.S. Army War College. Dallas, TX: Taylor Pub. Co., 1983.

Blumenson, Martin. “George S. Patton's Student Days at the Army War College.” Parameters 5, no. 2 (1976): 25-32.

Cartwright , Carl J. "The Education and Development of Senior Leaders from 1919-1940: Is There Relevance Today?” United States Army War College 2000.

Chairman of the Joint Chiefs of Staff Instruction, Officer Professional Military Education Policy, CJSC 1800.01D, 05 September 2012.

Chairman of the Joint Chiefs of Staff, Report of the Panel on Joint Professional Military Education of the Chairman, Joint Chiefs of Staff: A Strategic Vision for the Professional Military Education of Officers in the Twenty-first Century. Washington, DC: Chairman, Joint Chiefs of Staff, March 1995.

Chilcoat, Richard A. “The 'Fourth' Army War College: Preparing Strategic Leaders for the Next Century." Parameters Winter 1995-96: 3-17.

Colarusso, Michael J., and David S. Lyle. "Senior Officer Talent Management: Fostering Institutional Adaptability." Strategic Studies Institute and United States Army War College Press, February 2004.

Combined Arms Research Library Digital Library, Fort Leavenworth History Collection, Army War College, Fort Leavenworth, Kansas, 1950-1951.

http://cgsc.contentdm.oclc.org/cdm/ref/collection/p4013coll4/id/337

created 09 September 2010.

Donovan, William R. and Lynn M. Burblaw. Aiming for Educated Officers: Curriculum Evolution in Early Professional Military Education in the United States, 1880-1914. College Station, TX: Texas A and M University, 02 February 2007.

Dudevior, Glen P. "Educating Officers for the $21^{\text {st }}$ Century." United States Army War College, 2000.

Eure, Leroy T. History of U.S. Military War Colleges. Newport, R.I., Naval War College, 1959.

Goldwater Nichols Department of Defense Reorganization Act of 1986. Public Law 99-433. 99 Cong., 1 October 1986. 
Hodges, H. Charles, Jr. “The United States Army War College: Time for a Change.” United States Army War College, 2012.

Lawrence, Kirk. "Developing Leaders in a VUCA Environment." University of North Carolina Executive Development Program. March 2013. http://www.kenanflagler.unc.edu/executive-development.

Martin, Gregg F., and John W. Yaeger. "Break Out - A Plan for Better Equipping the Nation's Future Strategic Leaders." Joint Forces Quarterly 73, $2^{\text {nd }}$ Quarter 2014, 39-43.

McCausland, Jeffrey D. Educating Leaders in an Age of Uncertainty - The Future of Military War Colleges, the 2004-2005 Report to the Smith-Richardson Foundation. Carlisle, PA: Dickinson College, 2005.

Newland, Samuel J. “A Centennial History of the US Army War College.” Parameters 31, no. 3 (August 2001): 34-42.

Pappas, George S. Prudens Futuri: The US Army War College 1901-1967. Marceline, MO: Walsworth Pub. Co., 1967.

RAND Army Research Division, Research Programs. http://www.rand.org/ard.html (accessed 10 December 2014).

Reed, Brian J. Leader Development, Learning Agility and the Army Profession. Washington, DC: Association of the United States Army, October 2012.

Schifferle, Peter J. America's School for War: Fort Leavenworth, Officer Education, and Victory in World War II. Lawrence, KS: University of Kansas Press, 2010.

Stiehm, Judith Hicks. The U.S. Army War College: Military Education in a Democracy. Philadelphia, PA: Temple University Press, 2002.

Wong, Leonard, Stephen Gerras, William Kidd, Robert Pricone, Richard Swengos. "Strategic Leader Competencies.” United States Army War College, September 2003.

United States Army Combined Army Center, The Human Dimension White Paper: A Framework for Optimizing Human Performance, 09 October 2014.

United States Military Academy, The Undergraduate Journal of Social Sciences Presents: Congressman Ike Skelton, http://www.usma.edu/sosh/siteassets/sitepages/UJSS\%20Interviews/Skelton_Interview.p df (accessed 14 December 2014).

U.S. Army TRADOC, Operational Environments to 2028: The Strategic Environment for Unified Land Operations, August 2012. 
U.S. Army TRADOC Pamphlet 525-3-1, The U.S. Army Operating Concept: Win in a Complex World, 07 October 2014

U.S. Army TRADOC Regulation 10-5-6, Organizations and Functions: United States Army War College, 15 September 2005.

United States Army War College, USAWC 113 th Birthday Video; 6 min., 04 sec., http://youtu.be/MS3Yu4dK_W0 published 08 December 2014.

United States Army War College, Curriculum Catalog, Academic Year 2009-2010, Carlisle Barracks, 2009.

United States Army War College, Curriculum Catalogue, Academic Year 2011-2012, Carlisle Barracks, 2011.

United States Army War College, Curriculum Pamphlet, Academic Year 2003, Carlisle Barracks, 2003.

United States Army War College, Curriculum Pamphlet, Academic Year 2012, http://dde.carlisle.army.mil/DDE_documents/Catalogue.pdf (accessed 14 October 2014).

United States Army War College, The Torch, Spring 2014. http://www.carlisle.army.mil/banner/torch.pdf (accessed 02 December 2014).

The United States Army War College, "Military Level 1Programs" online at http://www.carlisle.army.mil/programs/mel_1.htm (accessed 07 December 2014).

U.S. House. Another Crossroads? Professional Military Education Two Decades After the Goldwater-Nichols Act and the Skelton Panel. Report on Professional Military Education, House Armed Services Committee, Subcommittee on Oversight and Investigations, April 2010.

U.S. Navy MILPERSMAN 1301-904, Service Colleges, 11 July 2013.

War Department General Orders, No. 155. Dated 27 November 1901, http://www.history.army.mil/documents/1901/WDGO155-1901.htm (accessed 02 December 2014).

Yarrison, James L., The U.S. Army in the Root Reform Era, 1899-1917, United States Army Center of Military History, 03 May 2001 http://www.history.army.mil/documents/1901/Root-Ovr.htm (accessed 27 November 2014). 